\title{
Indledning til RvT 71: dyr, natur, religion
}

Temanummeret her handler om den betydning, religiøse samfund har tillagt naturen, især planter og dyr. Emnet er nærliggende i lyset af klima- og biodiversitetskrisen, og det er centralt i mange religiøse symbolkomplekser. Krisen har aktualiseret et gammelt filosofisk tema, ontologi - dvs. læren (eller diskussionen) om det værendes beskaffenhed, herunder forskelle og ligheder imellem mennesker, dyr og planter og andre væsener (og guder og ånder eller samfund og nationer). Også i dele af aktuel antropologi er ontologi blevet et aktivt diskussions- og konfliktfelt. Er den moderne virkelighedsforståelse indlysende stærkere, rigtigere og mere lykkebringende end andre og tidligere virkelighedsforståelser? Artiklerne i dette nummer sammentænker på forskellig måde religiøse og nutidigt-ontologiske problemstillinger.

Temanummerets indledende artikel af Lars Albinus giver en oversigt over dyrenes betydning i religion og filosofi fra fortid til nutid. Trods mange kulturelle variationer har mennesker til alle tider haft en tendens til at spejle sig i dyret og dyret i sig selv. Samtidig ser vi hos forskellige stammefolk en tilbøjelighed til at forbinde dyrene med hellige egenskaber, hvis de ikke ligefrem ses som inkarnationer af guder og forfædre. Som de levende væsner, mennesket omgiver sig med i denne verden, synes de samtidig, i deres hemmelighedsfulde, mentale utilgængelighed, at repræsentere noget fremmed. Det er artiklens tese, at man med henblik på dyrets symbolske betydning kan tale om en immanent transcendens. Talrige eksempler fra forskellige religioner, såvel i arkaisk tid som hinsides den aksiale vending, viser, at dyr, i særdeleshed fugle, ofte ses som formidlere mellem den guddommelige og den menneskelige verden. Dog sker der generelt et skifte fra en symbolsk til en metaforisk betydningstilskrivning, der vidner om en kristent påvirket underordning af dyrenes egenværdi. Dette kommer også til udtryk i den vestlige verdens filosofiske opfattelse af dyrene som umælende væsner, der danner kontrast til mennesket som exceptionelt fornuftsvæsen. Et voksende opgør med denne antropocentriske exceptionalisme (også omtalt som speciesisme) har gennem længere tid været med til at sætte en ny dagsorden, dels inden for en antropologisk og øko-kritisk diskurs (ofte af feministisk tilsnit), dels i nyere filosoffers afstandstagen til forestillingen om et selvberoende fornuftssubjekts ultimative forrang. Artiklen inddrager både den aktuelle antropologiske diskussion hos bl.a. Philippe Descola, Tim Ingold, Eduardo Viveiros de Castro om det ontologiske forhold imellem mennesker og dyr og den parallelle filosofiske problemstilling hos den filosofihistoriske tradition, fx Montaigne, Descartes, Heidegger, og helt aktuel filosofi hos bl.a. Gilles Deleuze, Felix Guattari, Jacques Derrida og Giorgio Agamben. Alle stiller de kritiske 
spørgsmål til den måde, hvorpå mennesket drager en selvbeskyttende grænse mellem sig selv og andre dyrearter. Et hovedbegreb, som Agamben i den forbindelse gør brug af, er 'det nøgne liv' som udtryk for det sårbare eksistensvilkår, alle levende væsner har til fælles, og som kalder på en ny forståelse i en tid, hvor klimaet og biodiversiteten belastes i katastrofal grad.

Nicolai Krejberg Knudsen præsenter i sin artikel en filosofisk kritik af det posthumanistiske opgør med antropocentrismen og kan som sådan ses i forlængelse af Albinus' artikel. Det er en af Krejberg Knudsens hovedpointer at skelne mellem ontologiske, epistemiske og etiske aspekter af antropocentrismen. Problemstillingen fremstilles dermed i den kompleksitet, der er en forudsætning for seriøst at kunne tage stilling til den. Forfatteren tager udgangspunkt i den filosofiske fænomenologi, der ganske vist fokuserer på menneskets forhold til verden, men som fra Husserl til Heidegger forskyder problemstillingen fra mennesket som erfarende subjekt til Dasein (ordret: dér-væren) som den menneskelige erfarings egen forudsætning. Dermed rejser der sig også for Heidegger et spørgsmål om forskellige måder at være i verden på, udtrykt gennem hans tese om stenen som verdensløs, dyret som verdensfattigt og mennesket som verdensbyggende. Aktuelt afviser filosoffen Timothy Morten, at det kun skulle være mennesket, der har et egentligt forhold til verden; der er derfor brug for en alternativ verdensopfattelse, som tager højde for alle levende væsners komplekse interaktion med hinanden. I samme ånd fremstiller en af posthumanismens prominente fortalere, Rosi Braidotti, antropocentrismens 'artshierarkier' som etisk problematisk. I disse indvendinger, som i dag indtager en fremherskende plads, blandes de ontologiske, epistemiske og etiske aspekter imidlertid sammen. Når dette er vigtigt at understrege for Krejberg Knudsen, skyldes det bl.a., at han nok betragter Heideggers tænkning som antropocentrisk i ontologisk forstand (ikke at forveksle med den betydning, hvormed Descola anvender ontologi-begrebet), men netop ikke i epistemisk og etisk henseende. Menneskets - eller rettere: Daseins - excentriske væremåde står allerede i sit selvforhold i relation til andre væsener. Det er med andre ord den menneskelige væremådes forhold til verden, der overhovedet muliggør en ikke-antropocentrisk epistemologi og etik. I den forstand er Heideggers fænomenologi mere end noget andet antropoexcentrisk, hvorfor en ikke nærmere specificeret anklage for antropocentrisme ikke blot rammer skævt i forhold til hans fundamentalontologiske perspektiv, men heller ikke udviser en tilstrækkelig forståelse af kritikkens egne forudsætninger.

Dette temanummers øvrige artikler trækker i særlig grad på den nævnte franske antropolog, Philippe Descolas, ontologi. Hans J. Lundager Jensens artikel indfører i Descolas begreber med særligt henblik på deres religionsvidenskabelige relevans. I artiklen kombineres de ontologiske kategorier animisme, totemisme, analogisme og naturalisme med Robert Bellas historiske skelnen imellem tribal, arkaisk, aksial og postaksial religion. Animisme og totemisme er kendetegnende for tribale religioner. I begge disse ses mennesker og dyr som sidestillede. Både arkaisk og aksial religion er funderet på analogisme; her indgår guddommelige væsner, mennesker, dyr og planter i en hierarkisk og harmonisk orden. I moderniteten, efter at kristendommen og de andre store religioner har mistet deres monopol på virkelighedsopfattelsen, dominerer 
en naturalistisk ontologi, hvor en entydig natur står over for en uendelig variation i menneskelige kulturer, normer og perspektiver. De øvrige anskuelsesformer kan dog dukke op i partikulære sammenhænge.

I en korttillægsartikel demonstrerer Lundager Jensen en konkret brug af Descolas begreber, som samtidig viser utilstrækkeligheden i Lévi-Strauss' opfattelse af animismen. Det handler om et sydamerikansk myte-ritual-kompleks, der ikke, som hos LéviStrauss, bør forstås ud fra natur-kultur-kontrast, men som eksempel på en animistisk fællesidentitet mellem mennesker og dyr. Det betyder også, at Lévi-Strauss' forsøg på at vise, at de amerindiske myter tematiserer et brud i kommunikationen mellem himmel og jord, ikke lader sig opretholde.

Resten af nummerets artikler handler om forskellige religioners konkrete forhold til naturen. I Jørn Borups bidrag får vi et indblik i diverse aspekter af buddhismens omverdensforståelse. Både i traditionsinterne og vestlige diskurser tages især pali-litteraturen og den østasiatiske buddhisme til indtægt for et økologisk verdenssyn. Belægget findes både i theravada- og mahayana-traditionens interaktionistiske opfattelse af altings holistiske sammenhæng, ligesom medfølelsen med alle levende væsner og ikke-voldsprincippet spiller en konstituerende rolle. Svaret på, hvorvidt hunden har en Buddha-natur, som er det spørgsmål, der stilles i artiklens titel, er således et klart ja, for 'alle ting har buddhanatur', som det lyder i Mahāparinirvāṇa Sutra. Samtidig gør Borup imidlertid opmærksom på det forhold, at den soteriologiske side af buddhismen ikke interesserer sig så meget for naturen i sig selv, men snarere gør den til en scene for frigørelsen af samsāra, genfødslernes kredsløb. I den forstand er buddhismen fra begyndelsen en (med Bellahs betegnelse) aksial bevægelse. Det betyder dog ikke, at Borup anser den moderne, neo-animistiske dagsorden, der associeres med den, for illegitim. Den fortsatte konstruktion af traditionen, som nutidige øko-buddhistiske idealer bidrager til, er tværtimod en levende del af traditionen selv.

Hos Marianne Qvortrup Fibiger får vi et indblik i den hellighed, der i de forskellige former for hinduisme tilskrives træet. Hun påpeger således, at der grundlæggende er tale om en kontinuert opfattelse af træernes kosmologiske betydning fra tribal religion over arkaiske og aksiale udviklinger til nutidens religionsformer, ikke mindst i samtidens øko-dharma-bevægelse. Dagligt foretager forbigående hinduer en tilbedelse ( puja) af byens hellige træer, særligt banyan-træet og peepaltræet (eller figentræet, ficus religiosa). Mens sidstnævnte også er kendt som det træ, under hvis skygge Buddha efter 49 dage opnåede sin oplysning, udgør banyan-træet den konkrete manifestation af upanishade-digtningens 'evige banyan-træ', der i sin kosmologiske betydning kan sammenlignes med den nordiske mytologis Yggdrasil. Udover at vise kontinuiteten i trækulten gennem de forskellige perioder efter Bellahs opdeling benytter Qvortrup Fibiger sig ligeledes af Descolas ontologier, hvorved hun viser, hvorledes en rearkaisering gør sig gældende i den tilbedelse af træerne, der kobles sammen med en globaløkologisk appel hos nutidens reform- og guruorienterede bevægelser. Artiklen er endvidere illustreret med forfatterens egne fotografier.

Med en filologisk anlagt artikel præsenterer Lasse Løvlund Toft os for centrale, oversatte tekstuddrag, der demonstrerer forskellige kristne opfattelser af menneskets 
forhold til dyrene i det 4 . århundredes øst-kirkelige diskurser. Der er ikke uden videre, som det almindeligvis antages, tale om et ubetinget herre-tjener-forhold, men om divergerende opfattelser af den (med Descolas begreb) analogistiske relation, mennesket indgår i til dyrene før og efter syndefaldet. Et generelt træk ved de forskellige eksegetiske traditioner er imidlertid den udfordring, som de vilde, kødædende dyr skaber i relation til spørgsmålet om Guds retfærdighed (theodicé). Løvlund Toft gør i den forbindelse opmærksom på forskellen mellem en alexandrinsk og en antiokensk skole, hvor den første angiveligt opfattede forholdet mellem mennesker og dyr ud fra en "relationel kontinuitet", mens den sidste antog en "relativ diskontinuitet". Ifølge de antiokenske fædre bevarede Adam således ikke sin oprindelige magt over de vilde dyr efter uddrivelsen fra Edens Have. I modsætning til alexandrinernes opfattelse af en kontinuert skabelsesorden henviser antiokenerne således til syndefaldet som forklaring på rovdyrenes farlighed for mennesker. Samtidig danner dette perspektiv ifølge Løvlund Toft baggrund for en dybere forståelse af den tidlige hagiografiske litteraturs fremstilling af hellige personers særlige evne til at tæmme de rovdyr, de møder i arenaen eller under deres asketiske ophold i vildmarken. Desuden drager forfatteren en perspektiverende forbindelse til den vest-kirkelige tradition og en moderne zoologisk diskurs, der i sekulariseret modsætning til den patristiske skabelsestanke tager udgangspunkt i menneskets domesticering af anvendelige dyr samt varetagelse af de vilde dyrs overlevelseschancer.

Nummeret afsluttes med Katrine Frøkjær Baunvigs "Den herligste tidsfordriv", der med dansk guldalderdigtning som omdrejningspunkt udgør en kulturhistorisk fremstilling af menneskets syn på naturen, såvel den indre som ydre. Under inddragelse af Descolas ontologityper viser hun, hvorledes en stigende verdensfremmedhed, der følger i kølvandet på naturalismen, i 1800-tallet modvirkes af romantikkens genfortryllelse af verden. Her indtager ikke mindst dyrene en hovedrolle. En ny kobling mellem Karl Marx og H.C. Andersen viser desuden, hvorledes selv tingene får en reanimeret status. I en kristen sammenhæng er det Grundtvig og Ingemann, som i deres salmedigtning er eksponenter for genfortryllelsen, og her er det engle frem for dyr og ting, der stimulerer fantasien. Hovedtemaet er imidlertid H.V. Kaalund og J.Th. Lundbyes Fabler for Børn, hvor det naturlige liv, der anskues i forhold til børn og dyr, fremtræder som et idyllisk modperspektiv til de voksnes verden. Forfatteren hensætter os i en tid, hvor den danske 'hygge' udspillede sig i et herligt, men også moralsk opdragende tidsfordriv.

I samme ånd bydes læseren velkommen til dette temanummer om dyr, natur og religion.

Lars Albinus, lektor, dr. theol. Afdeling for Religionsvidenskab, Aarhus Universitet

Hans J. Lundager Jensen, professor, dr. theol. Afdeling for Religionsvidenskab, Aarhus Universitet 